\title{
CIVIL SOCIETY AND DISASTER MANAGEMENT: CASE OF MARMARA EARTHQUAKE
}

\author{
AFET YÖNETİMI VE SİVIL TOPLUM: MARMARA DEPREMİ ÖRNEĞİ
}

\author{
Güneş ERTAN ${ }^{1}$
}

\begin{abstract}
Despite the abundance of studies on performance of public organizations involved in the disaster management system of Turkey, there had been limited attention to the role of civil initiatives involved in disaster management. The disaster response operations in the aftermath of the Marmara earthquake showed that the interaction between public organizations and civil society organizations, and the coordination among the civil society organizations themselves have been very limited. After reviewing the literature on interorganizational response systems following the Marmara Earthquake, this study uses a novel data set to decipher the collective action problems of civil society organizations in Turkish disaster response system using network analysis. The study concludes with a set of policy recommendations to enhance coordination and cooperation among organizations involved in the governance of Turkish disaster management system.
\end{abstract}

Keywords: Disaster management, civil society, social networks

\section{Öz}

Türkiye'nin afet yönetim sistemine dahil olan kamu kuruluşlarının performansı konusunda çok sayıda akademik çalışma bulunmaktadır. Ancak afet yönetiminde yer alan sivil inisiyatiflerin rolüne sınırlı bir ilgi gösterilmiştir. Marmara depremi sonrasında gerçekleşen afet müdahale operasyonları, kamu kuruluşları ile sivil toplum kuruluşları arasındaki etkileşimin ve sivil toplum kuruluşları arasındaki koordinasyonun çok sınırlı olduğunu göstermiştir. Bu çalışma Marmara depreminden sonra gerçekleşen örgütler arası işbirliklerini inceleyen bir literatür taraması yaptıktan sonra yeni bir veri seti kullanarak Türkiye afet müdahale sistemindeki sivil toplum kuruluşlarının kolektif eylem sorunlarını ăg analizi kullanarak incelemektedir. Çalışma, Türk afet yönetişim sisteminde yer alan kuruluşlar arasındaki koordinasyonu ve işbirliğini geliştirmek için bir dizi politika önerisiyle sonuçlanmaktadır.

Anahtar Kelimeler: Afet yönetimi, sivil toplum, sosyal ağlar.

\footnotetext{
${ }^{1}$ Dr. Öğr. Üyesi, Koç Üniversitesi İktisadi ve İdari Bilimler Fakültesi, gunesertan@ gmail.com, Orcid:0000-0002-7997-6748
}

Makale Türü: Araşstırma Makalesi - Geliş Tarihi : 01/07/2019 - Kabul Tarihi: 10/07/2020

DOI:10.17755/esosder.585089

Atıf için: Elektronik Sosyal Bilimler Dergisi, 2020; 19(76):2044-2056. 


\section{Introduction}

The high level of disaster risk in Turkey is well-acknowledged by scientists, policy makers, and policy analysts. On the other hand, as revealed by the catastrophic social, economic, and environmental impacts of the twin earthquakes in Marmara region in 1999, disaster response system in Turkey is still far from being effective in terms of reducing the level of vulnerability and increasing the resilience of communities living in high risk regions.

On August 17, 1999 the region between Bolu and Istanbul was hit by a strong earthquake for 45 seconds (7.6 on the Richter Scale). According to official numbers 17,127 people were killed and 43,959 injured. The economic damage is estimated to be between US\$9 and \$13 billion (DPT, 1999).The scholarly work preceding the Marmara earthquake mostly focused on government failure that turned a natural disaster into a social one. The Turkish state neither had the capacity, nor an appropriate plan to manage a crisis of this intensity (Jalali, 2002; World Bank, 1999). Many scholars and practitioners criticized the performance of public agencies due to lack of slow and inadequate response and relief operations (e.g. Jalali, 2002; World Bank, 1999; Kubicek, 2002; Bakir and Boduroglu, 2002), inadequacy of response plans in all levels of government (Boduroglu, 1999; Erkoc, 2001), high levels of corruption among government officials that obstructed the enforcement of building and safety regulations which dramatically contributed to the large number of human losses (Istanbul Technical University, 1999; Ozerdem and Jacoby, 2005; Ozerdem and Barakat, 2000; Kubicek, 2001); and very centralized and top-down perspective on disaster management (Karanci and Aksit, 2000; Ergunay, 1999).

Despite the abundance of studies on performance of public organizations involved in the disaster management system of Turkey, there had been limited attention to the role of civil initiatives involved in disaster management. Numerous civil society organizations (CSOs) following the Marmara Earthquake were on the ground during the emergency response and recovery efforts. The presence of large number of CSOs in disaster response was a first in the history of Turkish republic. Participation of Turkish CSOs in disaster response was a welcomed event by experts in all sectors. However the emergence of diverse and large number of nongovernmental actors within the disaster management system raised very important policy issues such as the integration of CSOs to the formal disaster management system, and the challenge of cooperation of the CSOs within themselves to maximize the effectiveness of their resources.

The experience of disaster response in the aftermath of the Marmara earthquake showed that the interaction between public organizations and CSOs, and the coordination among the CSOs themselves have been very limited. After reviewing the literature on interorganizational response systems following the Marmara Earthquake, this study uses a novel data set to decipher the collective action problems of CSOs in Turkish disaster response system using network analysis. The study concludes with a set of policy recommendations to enhance coordination and cooperation between organizations involved in the governance of Turkish disaster management system. 


\section{Interaction between CSOs and Public Organizations Following the Marmara Earthquake}

Turkey is generally described as having a strong, centralized state tradition and a weak civil society. Heper and Yildirim (2011) consider pervasive populism, clientelism, opportunism, and personalism, scarcity of tolerance, lack of altruism, and pluralism as the main reasons for the weakness of civil society in Turkey. High level of participation of CSOs in disaster response and recovery operations following the Marmara earthquake is considered as the single most important positive outcome of the Marmara earthquake. According to the Third Sector Foundation of Turkey (TUSEV) Marmara earthquake is among the three most crucial events that contributed to the development of civil society in Turkey (others include EU admission process, and 1996 UN Habitat Conference II (Ozerdem and Jacoby, 2006). Kubicek (2002) argues that state's inability to respond effectively generated a justification for the activities of the CSOs and created a social and physical space for CSOs to operate.

While the involvement of CSOs in response operations is a progress in terms of capacity of Turkish civil society and disaster management system, the interaction of the CSOs and public organizations were far from being constructive. In some instances, state officials closed down the CSOs' depots for donated goods and threatened to turn off electricity if the administration was not transferred to them (Jalali, 2002). Several organizations' bank accounts were frozen by the government in order to regulate the emergency relief and ensure that all the funds for victims were channeled through the state (Kubicek, 2002). Moreover, following the increased popularity of these organizations through visual and print media praising their activities, government introduced a new regulation that required all relief groups to go through tedious registration procedures before they could operate (Kubicek, 2002).The Ministry of Public Works and Reconstruction refused to give permission to the Turkish Association of Architects and Civil Engineers to continue its voluntary operations in the inspection of damaged and destroyed buildings (Ozerdem and Jacoby, 2006). The Ministry of Health filed charges against the AKUT (a search and rescue team with high levels of public support and popularity), for not having proper authorization (Ozerdem and Jacoby, 2006).

The tensions between CSOs and state were most blatant in the case of Islamist and leftist organizations whereas state friendly CSOs had more space to operate (Jalali, 2002). Islamists organizations worked closely with local and provincial administrations that were governed by the representatives of the Islamist political party, but they encountered many discriminations from central bureaucracy and military. Some Islamist organizations such as the Organization of Human Rights Solidarity for Oppressed People argued that the government limited its ability to function during the response period by closing not only its donation accounts but also general accounts (Kubicek, 2001). On the other hand, many state-friendly organizations at the time such as the Human Resource Development Foundation, had difficulties in working with elected Islamists local governors while they worked closely with military and national level state agencies (Kubicek, 2001). 
One of the most important reasons for state agencies reluctance to work with the CSOs was the declining popularity of the ruling coalition government consisting of Democratic Left Party (DSP), Motherland Party (ANAP), and Nationalist Movement Party (MHP) (Ozerdem and Jacoby, 2006). A similar observation is made by Sobel and Leeson (2006) in their analysis of the government response to the hurricane Katrina. According to Sobel and Leeson, in times of disasters, public organizations may not be willing to cooperate with nonprofit or private organizations in order to take more credit for response operations and they call this behavior as "glory seeking behavior". In addition to that, the Turkish political culture that stresses authority over citizen empowerment and participation is another important factor that limited the operations and coordination efforts of the CSOs (Ertan, 2018). As Heper (1985) argues, Turkish state elite typically distrusts civil society and believes that an uncontrolled civil society would produce social divisions.

There are a number of reasons for considering this issue as a policy problem and expanding the operating space for CSOs in the aftermath of disasters. First of all, the first 72 hours after a disaster is the critical period for search and rescue operations, and during this period large organizations such as public agencies may be unable to mobilize quickly (Ozerdem and Jacoby, 2006). CSOs have higher levels of flexibility since they are relatively free from bureaucratic structures and better able to respond and adapt quickly and easily (ISDR, 2006). Secondly, CSOs work with the communities and take a participatory approach to their operations. Therefore they may be better at responding to the needs of the local people (ISDR, 2006). Karanci and Aksit (2000) also argue that CSOs are crucial in understanding and incorporating the attitudes, expectations, and resources of the local communities in order to develop plans that can be integrated into the ongoing social life of the communities in disaster prone areas. Moreover, there is an increasing trend among the international donor community to channel funds for disaster relief through international and national CSOs rather than directly through national governments. Therefore, the effective utilization of these resources require the governments to embrace CSOs into all levels of the national administrative structure (UNDRR, 1998). In addition to these since majority of the CSOs working in disaster management are also involved in development related projects and programs these organizations are already working with the poorest segments of the society that are much more vulnerable for any kind of disaster (ISDR, 2006; Twigg and Steiner, 2002). Hence CSOs have various operational advantages in terms of local knowledge and expertise on vulnerable populations (Bolin and Stanford, 1998). While there is no doubt that CSOs cannot be considered to perform the main tasks of public organizations, the above-mentioned comparative advantages of the CSOs make it necessary to consider how to better utilize the capacity of these organizations in disaster response policy.

\section{Coordination efforts of Civil Initiatives in the aftermath of Marmara Earthquake}

More than a three dozen CSOs made an effort to coordinate their activities by establishing a Civil Coordination Center (CCC) and using and independent radio station to match donations with the victims of the disaster since none of the organizations had the resources to deliver relief 
on such a large scale (Ozerdem and Jacoby, 2005). The organizations varied significantly with regards to the kind of activities they have conducted and the volume of the aid they provided. Most typical activities included search and rescue activities, medical assistance and provision of goods like tents, clothes, or simply money (CCAD, 2001).

Although, initiatives such as CCC generated an organized collective action among Turkish CSOs that increased their performance during the response operations, they were still not able to generate the kind of coherent force necessary to maximize the effectiveness of the allocation of their resources and skills (Ozerdem and Jacoby, 2005). As Jalali (2002) argues, the coordination among CSOs took place mostly among the organizations that shared similar political ideologies.

Not surprisingly, the deeply divided social structure of the Turkish society was reflected within the coordination efforts of the CSOs. The divisions between the liberals and conservatives, secularists and the Islamists, nationalists and the Kurdish activists, and conservative Sunnis and the Alevis were manifested within the interaction of the CSOs during the response operations (Kubicek, 2002). According to Kubicek (2002), none of these groups worked with each other and the Civil Coordination Center, which was supposed to be the principle organization that was responsible for the coordination activities, became the coordination center for only liberal groups such as the Human Settlement Foundation, Human Resource Development Foundation, and Women's Labor Evaluation Foundation.

These observations are problematic since increasing the coordination among CSOs is critical to maximize the efficient of use of limited resources, as well as to enhance the accountability and effectiveness of the CSOs activities (Rey,1999). Empirical evidence also shows that more central and visible organizations involved in disaster management network are likely to be more effective than the organizations that are working in isolate. For example, using social network analysis, Moore et al. (2003) show that during the Mozambique floods in 2000, the humanitarian aid organizations with high levels of centrality measures were more effective in their aid operations (measured as the number of beneficiaries). Consequently, in order to avoid duplication and to complement different types of resources, coordination of CSOs in a disaster environment is very crucial (UNDRR, 1998).

\section{Coordination of CSOs as a Collective Action Problem}

As the discussion of the coordination efforts of Turkish CSOs following the Marmara earthquake shows, the policy problem in hand is a problem of collective action. There are large number of studies from different theoretical traditions that address the problem of collective action. Ostrom's (1990) theory of collective action is one of the prominent works that address under which social and local conditions collective action is feasible. In her seminal work, Governing the Commons, Ostrom tries to answer the fundamental question of collective action; "how a group of principals who are in an interdependent situation can organize and govern themselves to obtain continuing joint benefits when all face temptations to free-ride, shirk, or otherwise act opportunistically... how a group of citizens can organize themselves to solve the 
problems of institutional supply, commitment, and monitoring? (p.29)" . After investigating the similarities among enduring, self-governing Common Pool Resources Ostrom identifies the following conditions under which collective action is feasible: (1) Actors have the capacity to communicate with each other, (2) there is a significant level of trust among actors, (3) the external environment is not disabling for the collective action, (4)there are small scale physical boundaries, and (5)actors are homogenous to a great extent not only in terms of political, and cultural characteristics, but also in terms of their power either in the form of economic resources or in terms of their social and political clout. The lack of these internal and external factors is visible to some extent in the case of collective action efforts of the Turkish CSOs as discussed in the previous sections

\section{Data}

Network analysis is employed in order to identify the key actors and to understand the interaction patterns between public organizations and CSOs. Data for the analysis were provided through Civil Coordination Against Disasters (CCDA), a Turkish CSO that emerged aftermath the Marmara Earthquake as an extension of Civil Coordination Center. CCDA generated a database that included information about the Turkish CSOs that are currently working in disaster management. The information in the database is published as "Civic Coordination Guide" which includes a short summary of the CSOs disaster related work, as well as information about the organizations that are working together (CCDA, 2005). This database exclusively focuses on CSOs and does not provide any data about the interaction of public agencies among themselves. As Table. 1 demonstrates, there are 205 CSOs identified by CCDA that are currently working in disaster management. CSOs are categorized as non-governmental organizations, professional organizations, community organizations, search and rescue groups, and universities. 52 of CSOs are international aid and development organizations whereas 90 of them are national, 36 are provincial, and 18 are local level. In addition to CSOs, 87 public and 5 private organizations are identified to be working with CSOs by the CCDA database. These figures show that the number of local and provincial public organizations collaborating with CSOs significantly higher in comparison to public organizations operating at the national level.

Table.1 Number of Organizations involved in Disaster Management

\begin{tabular}{|c|c|c|c|c|c|c|c|c|}
\hline & Public & \%Public & CSOs & $\% \mathrm{CSOs}$ & Private & \%Private & $\begin{array}{c}\text { Total } \mathbf{N} \text { of } \\
\text { ALL } \\
\text { Organizations }\end{array}$ & $\begin{array}{c}\% \\
\text { All }\end{array}$ \\
\hline & $\mathbf{N}$ & $\%$ & $\mathbf{N}$ & $\%$ & $\mathbf{N}$ & $\%$ & $\mathbf{N}$ & $\%$ \\
\hline International & 11 & 3.7 & 52 & 17.5 & 0 & 0 & 63 & 21.2 \\
\hline National & 20 & 6.7 & 90 & 30.3 & 4 & 1.3 & 114 & 38.4 \\
\hline Provincial & 38 & 12.8 & 36 & 12.1 & 1 & 0.3 & 75 & 25.3 \\
\hline Local & 18 & 6.1 & 27 & 9.1 & 0 & 0 & 45 & 15.2 \\
\hline Totals & 87 & $29.3 \%$ & 205 & $69.0 \%$ & 5 & $1.6 \%$ & 297 & 100 \\
\hline
\end{tabular}

Source: CCAD (2005), Civic Organization Against Disasters, YON:Istanbul 


\section{Mapping and Centrality Measures}

Using data provided by CCAD, one one-mode (Org X Org) non-valued and nondirectional matrix is created. Organizations are linked through collaborations, but there is no information about the nature of these collaborations. In order to identify the key actors in the network, Freeman degree centrality, closeness centrality, and betweenness centrality are generated for each organization involved in the system.

Table.2 Top 15 Organizations in Centrality Measures

\begin{tabular}{|c|c|c|c|}
\hline Rank & Degree Centrality & Closeness Centrality & Betweenness Centrality \\
\hline 1 & $\begin{array}{l}\text { Coordination Center Against } \\
\text { Disasters }\end{array}$ & $\begin{array}{c}\text { Coordination Center Against } \\
\text { Disasters }\end{array}$ & Coordination Center Against Disasters \\
\hline 2 & $\begin{array}{c}\text { Organization for Contemporary } \\
\text { Life }\end{array}$ & Ministry of Civil Defense & Organization for Contemporary Life \\
\hline 3 & Ministry of Civil Defense & $\begin{array}{l}\text { Organization for } \\
\text { Contemporary Life }\end{array}$ & Foundation for Health Education \\
\hline 4 & AKUT & $\begin{array}{l}\text { Foundation for Health } \\
\text { Education }\end{array}$ & $\begin{array}{l}\text { Human Resources Development } \\
\text { Foundation }\end{array}$ \\
\hline 5 & Bekirpasa Survivors Association & AKUT & Governorship of Istanbul \\
\hline 6 & Foundation for Health Education & Governorship of Istanbul & AKUT \\
\hline 7 & TRAC & AG17 & Bekirpasa Survivors Association \\
\hline 8 & AG17 & $\begin{array}{c}\text { Istanbul Environmental } \\
\text { Volunteers }\end{array}$ & AG17 \\
\hline 9 & $\begin{array}{l}\text { Association of Turkish } \\
\text { Psychologists }\end{array}$ & $\begin{array}{c}\text { Human Resources } \\
\text { Development Foundation }\end{array}$ & $\begin{array}{l}\text { Foundation for Support of Women's } \\
\text { Work }\end{array}$ \\
\hline 10 & Governorship of Istanbul & $\begin{array}{c}\text { Foundation for Support of } \\
\text { Women's Work }\end{array}$ & Istanbul Environmental Volunteers \\
\hline 11 & $\begin{array}{l}\text { Human Resources Development } \\
\text { Foundation }\end{array}$ & Red Crescent & Association of Turkish Psychologists \\
\hline 12 & Avcilar Solidarity Foundation & $\begin{array}{l}\text { Directorate of Social Serv. } \\
\text { \& Child Prot. }\end{array}$ & Avcilar Solidarity Foundation \\
\hline 13 & Women's Solidarity Foundation & $\begin{array}{l}\text { Istanbul Technical } \\
\text { University }\end{array}$ & TRAC \\
\hline 14 & Neighborhood Volunteers & $\begin{array}{l}\text { Istanbul Municipality Civil } \\
\text { Defense }\end{array}$ & Red Crescent \\
\hline 15 & $\begin{array}{l}\text { Organization for Human Rights \& } \\
\text { Oppressed }\end{array}$ & MEMISA & Neighborhood Volunteers \\
\hline
\end{tabular}

Freeman's Degree centrality measures the number of ties that each actor has with other actors. Higher an actor's degree centrality, the more direct contact that actor has with other actors in the network. Freeman's Degree Centrality provides us with limited information since it focuses solely on the local direct ties of an actor. Therefore, global measures of centrality are also considered. Closeness centrality provides the average distance of an actor to all other actors in the 
network. Lastly, betweenness centrality measures the degree to which certain actors may be influential due to their location that connect otherwise disconnected actors (Scott, 2000).

Most of the organizations that rank high in three of the centrality measures are very similar. CCAD ranks first in three of the centrality measures, and can easily be identified as the central actor of the network. Well-known liberal urban middle class CSOs such as the Organization for Contemporary Life, Foundation for Health and Education are also identified as central actors in the system. Ministry of Civil Defense, Governorship of Istanbul and General Directorate of Social Services and Child Protection are the only public organizations that rank high in centrality measures. Search and rescue organizations such as AKUT and TRAC also rank high in three of the centrality measures.

A well-known Islamist CSOs-Organization for Human Rights and Oppressed People, in Freeman's Degree Centrality, and its absence in other centrality measures that analyze the relative location of each actor. This finding shows that Organization for Human Rights and Oppressed People are connected to many other organizations that are not connected to the other important actors in the system. Similarly, Avcilar Solidarity Foundation, a local community based organization, also ranks relatively high only in Freeman's Degree Centrality implying that this organization is working with many other organizations that are very isolated from the overall network.

Next, interactions among public and CSOs are visualized. Blue nodes imply CSOs whereas red nodes imply public organizations. There are 16 isolates in the network that are not connected to any other actor. The sizes of the nodes show the degree centrality for each actorlarger nodes mean more direct connections. 


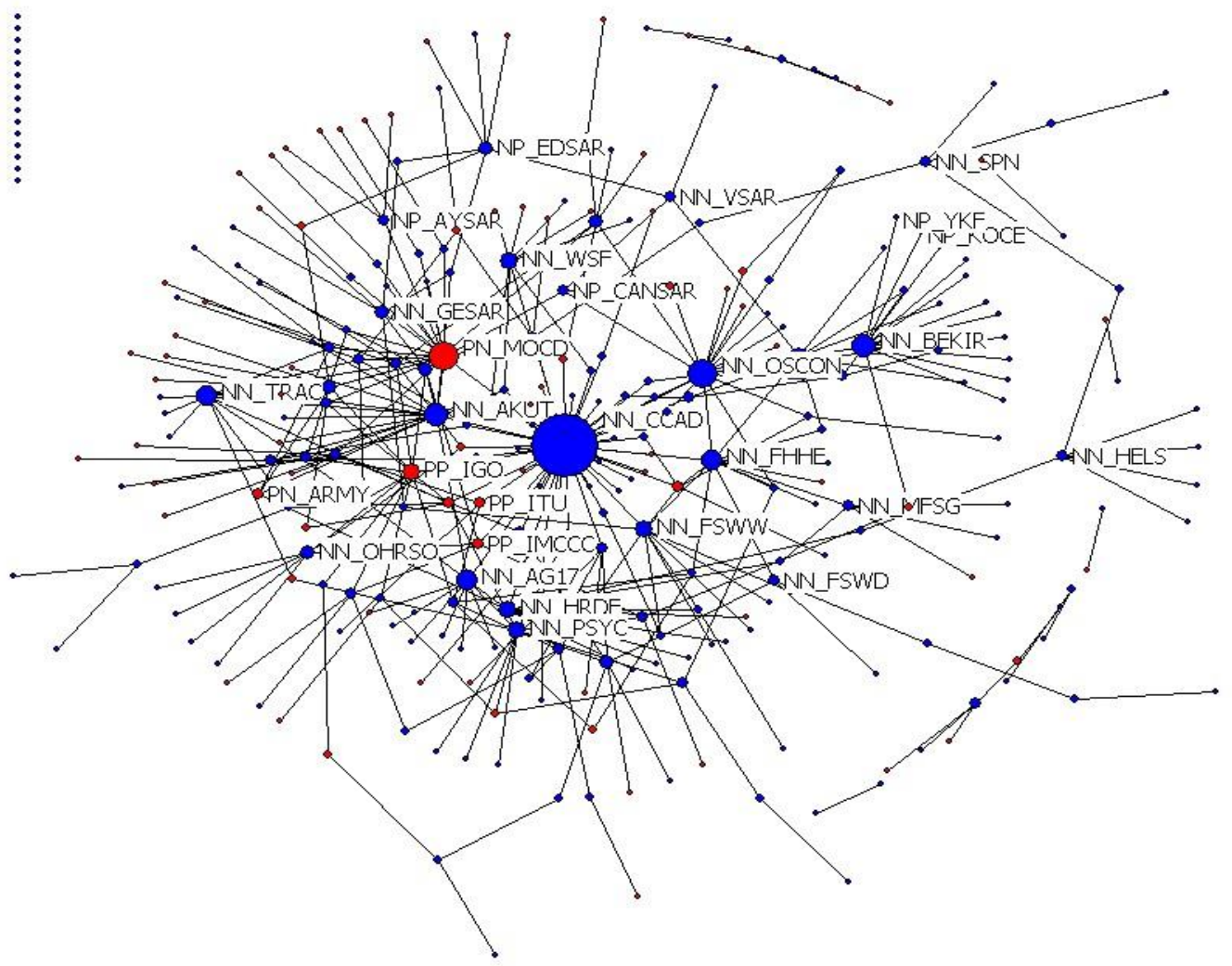

Figure.1 Interactions between Public Organizations and CSOs

Figure.1 clearly displays the limited interaction between public organizations and CSOs. Turkish army, Ministry of Civil Defense, and provincial level public organizations in Istanbul are the main public organizations that work with more than one CSO.

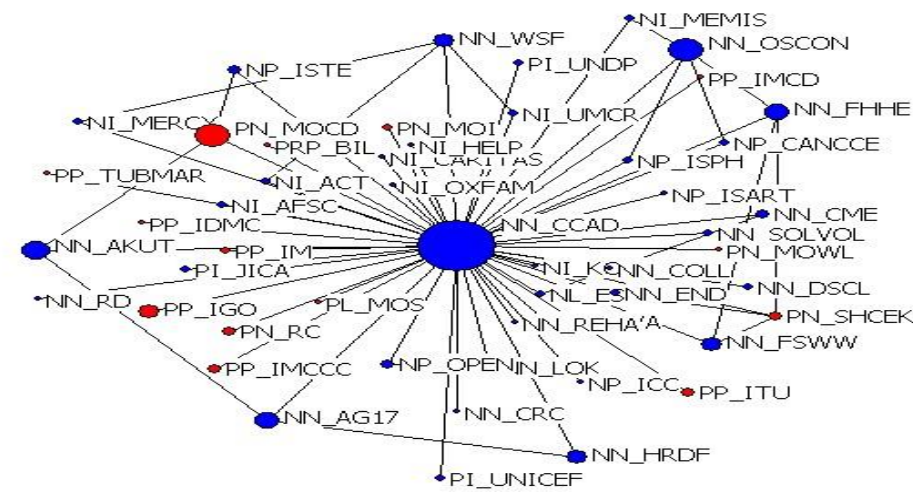

Figure.2 Egocentric network of CCAD 
As the egocentric network of CCAD shows, most of the CSOs that are connected to CCAD are organizations that represent urban, middle-class groups such as Organization for the Support of Contemporary Life, Foundation for the Support of Women Work, Open Radio, AKUT, and Lokman Hekim Foundation. Moreover, although the CCAD seems to be connected to many international public and non-profit organizations such as UNICEF, UNDP, JICA, and OXFAM, number of provincial and local organizations that are working with CCAD seems to be very limited.

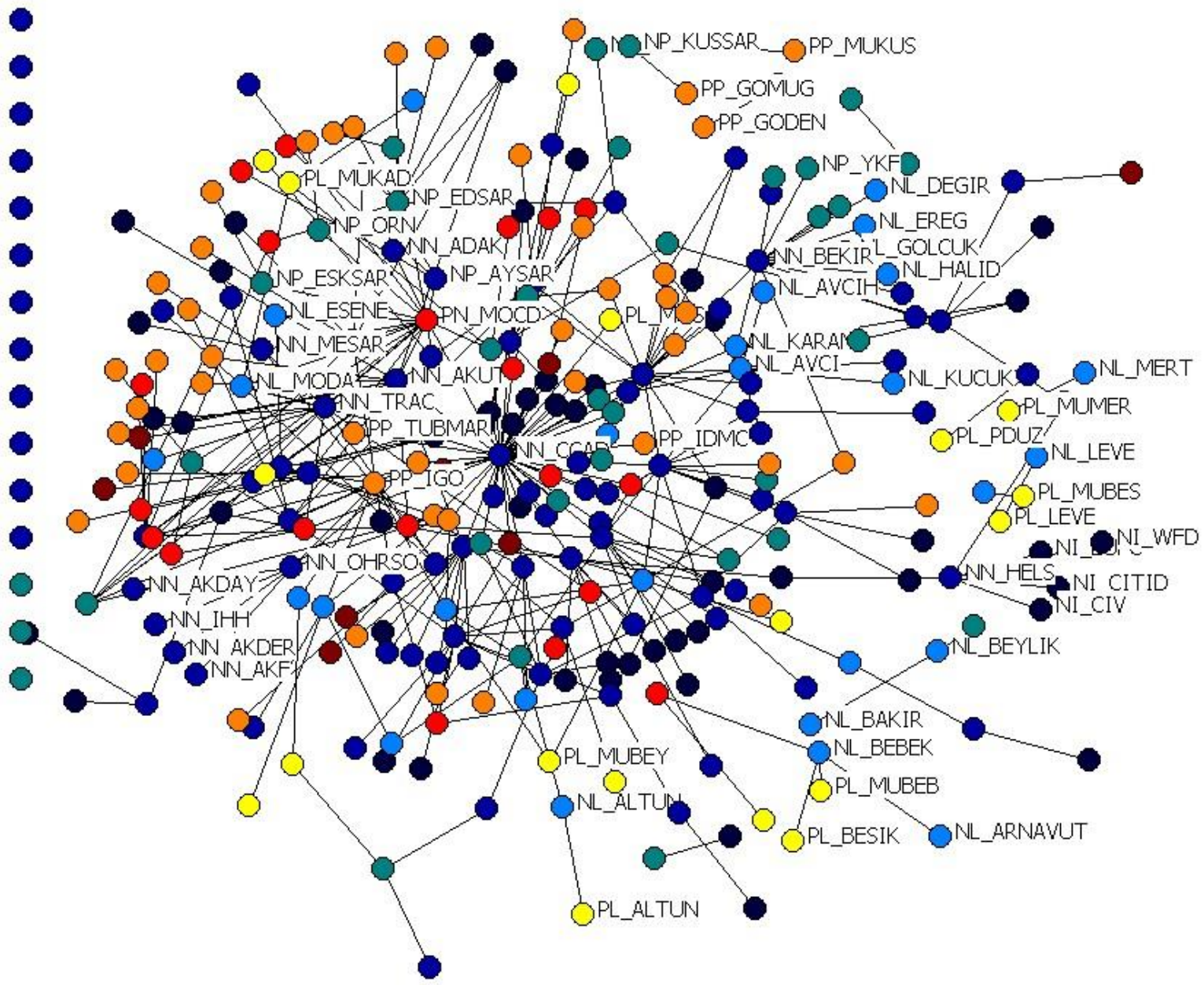

Key: International Organizations, Nationwide CSOs, Provincial CSOs, Local CSOs, National Public Organizations, Provincial CSOs, Local Public Organizations

Figure.3 Interactions between CSOs and Public Organizations in relation to different Jurisdiction Levels.

As Figure.3 shows, organizations with same or closer level of jurisdiction are likely to work together. Moreover, this figure makes it clear that most of the interaction taking place between CSOs and public organizations are taking place in the local level (e.g. the clique around NL_BAKIR, NL_BEBEK, PL_MUBEB, PL_BSEIK, NL_ARNAVUT). Therefore, any policy 
proposal aiming at the integration of CSOs with the formal disaster management system should address this issue not only in national level, as in the case of Turkey Emergency Management General Directorate, but also in the local level.

Figure. 3 also shows the cliques that emerge around different common characteristics. For example, there is a small and isolated clique around Islamist CSOs such as the Organization for Human Rights and Oppressed People (NN_OHRSO), Women Against Discrimination (AKDER), IHH and AK Foundation (AK). This phenomenon in network analysis terminology is called homophily. Homophily is the principle that a contact between similar actors in the network is likely to be more frequent than dissimilar actors (McPerson et al. 2001). Homophily may create problems if it is prevalent among the all network.

Overall there seems to be couple of sources of homophily; political ideology, function of the organizations, and jurisdiction level. Secular liberal NGOs are situated in the core of the network around the CCAD, where as Islamists and Leftist CSOs have their own relatively isolated cliques in the periphery of the network. Another striking but not surprising source of homophily is the function of organizations; for example SAR groups such as AKUT, MESAR, EDSAR, AYSAR, ADAK, and MUDAK form a clique. Lastly, level of jurisdiction also seems to be an important source of homophily in the network.

\section{Discussion and Conclusions}

The analysis highlights a number of important findings. There is a disconnect of coordination between organizations that operate at different levels of jurisdictions. There is limited interaction between CSOs and public organizations. Most of the existing interaction is taking place in local or provincial levels. Organizations included in the network are clustered around certain functions such as search and rescue, rehabilitation, education and public awareness. Overall, the network is far from being a cohesive one. Clusters of organizations are either disconnected or loosely connected to the civic coordination center. In order to institutionalize the collaboration between public and civil society organizations, protocols need to be developed between public organizations and CSOs that should clarify the responsibilities and capacities of CSOs working in disaster management. In addition to these, there is an urgent need to standardize the emergency response plans of CSOs and public agencies as well as to establish a common terminology of disaster management. Such a program can facilitate a coherent, effective and democratic disaster management system that will reduce Turkey's vulnerability to disasters and increase the resilience of communities that are living under high levels of disaster risk.

The divided and heterogeneous structure of Turkish civil society is reflected within the interactions of CSOs with different political ideologies in the form of untrusting attitudes and relations. The complex and large environment makes it very difficult for organizations in different levels of jurisdiction and different regions of the country to communicate effectively. One approach recommended by Nelson et al. (2004) to foster collective action among diverse group actors suggests (1) promoting shared overarching values among the organizations, (2) establishing rules of engagement and clarifying decision making mechanisms, and (3) preventing proselytizing is to recognize differences. In addition to these information and communication technologies may be better utilized in the aftermath of disasters such as SAHANA type of free and open source information management systems. 


\section{References}

Bakir, P.G., and Boduroglu, H. M. (2002). Earthquake risk and hazard mitigation in Turkey. Earthquake Spectra, 18 (3), 427-447.

Bolin , R. and L. Stanford .(1998). The Northridge earthquake: community based approaches to unmet recovery needs. Disasters 22 (2), 21-38.

Civic Coordination against Disaster (CCAD). (2005). A Guide to the civil society organizations that were active during the Marmara Earthquake. Istanbul: Iletisim (in Turkish).

DPT (1999) Depremin Ekonomik and Sosyal Etkileri: Muhtemel Finans Ihtiyaci (Economic and Social Impacts of the Earthquake: Possible Financial Needs)

Ergunay, O. (1999). A perspective of disaster management in Turkey: issues and prospects. urban settlements \& natural disasters. IUA- The Chamber of Architects.

Erkoc, T. (2001). Briefing on Marmara earthquakes from general directorate of disaster affair to the members of center for excellence for disaster management-Istanbul Technical University, SDKM, ITU, Istanbul.

Ertan, G. (2018). Policy analysis in civil society organizations, in: C. Bakir and G. Ertan Eds) Policy Analysis in Turkey (Bristol: University of Bristol: Policy Press), pp. 199-212.

Heper, M. (1985). The state tradition in Turkey. London: Eothen Press.

Heper, M. and Y1ldırım, S. (2011) "Revisiting civil society in Turkey", Southeast European and Black Sea Studies, vol 11 no1, pp 1-18.

International Strategy for Disaster Reduction (ISDR). (2006). Country report-Turkey.

Istanbul Technical University. (1999) Pre-assessment report for Marmara rarthquakes, (Ondegerlendirme Raporu).

Jalali, R. (2002). Civil society and the state: Turkey after the Earthquake. Disasters, 26(2), pp.120-139.

Karanci , N. and Aksit, B. (2000). Building disaster resistant communities: lessons learned from past earthquakes in turkey and suggestions for future. International Journal of Mass Emergencies and Disasters, 8 (3), 403-416.

Kubicek, P. (2001). The Earthquake, Europe, and Prospects for Political Change in Turkey, MERIA, 5 (2).

Kubicek, P. (2002). The Earthquake, civil society, and political change in Turkey: assessment and comparison with Eastern Europe. Political Studies, 50, pp.761-778.

McPherson, M. , Smith-Lovin, L. and Cook, J. (2001). Birds of feather: homophily in Social Networks. Annual Review of Sociology, 27, 415-44.

Moore, S., Eng, E. and Daniel, M. (2003). International NGOs and the role of network centrality in humanitarian aid operations: a case study of coordination during the 2000 Mozambique Floods. Disasters, 27 (4), pp. 305-318. 
Nelson, B. J., Carver, K. A. and Kaboolian, L. (2007). Creating concord organizations: institutional design for bridging antagonistic cultures. In: Helmut Anheier and Yudhishthir Raj Isar (eds.) Conflicts and Tensions. London: Sage, pp. 283-295.

Ostrom, Elinor. (1990). Governing the commons: the evolution of institutions for collective action. Cambridge, UK, New York: Cambridge University Press.

Ozerdem, A. and Jacoby, T. (2005). Disaster Management and Civil Society. New York: I.B. Tauris.

Ozerdem, A and Barakat, S. (2000). After the Marmara Earthquake: lessons for avoiding short cuts to disasters, Third World Quarterly, 21 (3), 425-439.

Rey, F. (1999). The nature of actors in humanitarian action and the challenge of coordination. The Humanitarian Studies Unit (Ed.) Reflections on Humanitarian Action: Principles, Ethics and Contradictions. Pluto Press: London.

Scott, J. (2000). Social Network Analysis. California: Sage Publications.

Sobel and Leeson (2006) Government's response to Hurricane Katrina: A public choice analysis. Public Choice, 127 (1), 496-509.

Twigg, J. and Steiner, D. (2002). Mainstreaming disaster mitigation: Challenges to organizational learning in NGOs. Development in Practice, 12 ,(4) pp.472-479.

UNDRR. (1998). Model for a National Disaster Management Structure, Preparedness Plan, and Supporting Legislation. Retrieved from https://www.preventionweb.net/files/5142_US01MH840-Ft.pdf.

UNDP.(2004).Reducing Disaster Risk: A Challenge for Development. Retrieved from http://www.undp.org/bcpr/whats_new/rdr_english.pdf

World Bank.(1999).Turkey Marmara Earthquake Assessment. World Bank Turkey Country Office, September. 